\title{
LEAF HERBIVORY BY CLOVER ROOT WEEVIL ADULTS - HOW MUCH DO THEY EAT?
}

\author{
P.J. GERARD and D.L. HACKELL \\ AgResearch, Ruakura Research Centre, Private Bag 3123, Hamilton, \\ New Zealand \\ Corresponding author: pip.gerard@agresearch.co.nz
}

\begin{abstract}
Populations of adult clover root weevil (Sitona lepidus) can inflict significant numbers of their distinctive feeding notches on the leaves of white clover (Trifolium repens) plants. However, it is assumed that because white clover is bred for defoliation, the damage on established plants has little impact. Two experiments were undertaken to quantify the daily leaf consumption levels of adult weevils, and how this varied with weevil size and sex, clover cultivar and previous leaf damage. Overall, adults consumed between 0.75 and $1.2 \mathrm{mg}$ dry matter/day depending on cultivar and sex. Sexual differences were observed between two contrasting clover cultivars, with females consuming more Grassland Prestige and males Grasslands Kopu. Clover dry matter loss through adult feeding was estimated at about $50 \mathrm{~kg} / \mathrm{ha}$ from early summer until midwinter in the Waikato, the period of peak adult activity.

Keywords: Sitona lepidus, clover root weevil, white clover, herbivory.
\end{abstract}

\section{INTRODUCTION}

Clover root weevil (CRW) (Sitona lepidus Gyllenhal (Coleoptera: Curculionidae)) is now regarded one of the most serious pests of white clover (Trifolium repens L.) in New Zealand. Larval feeding on clover roots causes the most serious damage to plants (Gerard et al. 2004). While losses of up to $27 \%$ of leaf area by adult Sitona spp. during the winter have been reported overseas (Clements \& Murray 1991), this leaf herbivory is regarded as unimportant, since pasture plant species such as white clover are well adapted for periodic removal of foliage.

Previous authors investigating the feeding preferences of adult CRW have obtained consumption data (Murray \& Clements 1994; Murray 1996a; Hardwick 1998) but in all cases the adults had been starved $24 \mathrm{~h}$ before being offered leaves excised from the plant. Prior starvation could result in an overestimate of normal feeding levels and it is possible that chemicals the plant may produce in response to attack, which may influence adult feeding preferences, would differ in attached and excised foliage. Mowat \& Shakeel (1989) reported strong correlations between Sitona spp. leaf damage and the cyanogenic potential of the 15 cultivars tested in the field. However, when cultivars were evaluated in the laboratory using excised leaves, no relationships between feeding levels and cyanogenic potential were apparent (Murray \& Clements 1993; Murray 1996b).

This paper reports on two experiments aimed at further investigating CRW adult feeding patterns.

\section{METHODS}

CRW adults used in the experiments were collected from a ryegrass (Lolium perenne L.)/white clover pasture close to Hamilton using a modified Homelite HB180V blower/ vac. Both experiments used adults from the field samples on the day of collection.

Controlled environment experiment

Five mature healthy white clover cv. Crau plants, grown in $15 \mathrm{~cm}$ diameter pots with a high nutrient status commercial potting mix, were placed in a temperature-controlled 
room at a constant $18^{\circ} \mathrm{C}$, light intensity of $220 \mu \mathrm{M} / \mathrm{m}^{2} / \mathrm{sec}$ and $16: 8 \mathrm{~h}$ light:dark periods. On each plant single adults were caged on a new fully-expanded leaf in a plastic Petri dish. A slot had been cut in the Petri dish base to hold the leaf petiole wrapped in cotton wool, and the lid had a $55 \mathrm{~mm}$ aeration hole covered with gauze. Petri dishes were held firmly closed by $75 \mathrm{~mm}$ bulldog clips, and in a vertical position by pushing one handle of each clip into the soil:pot interface. Five cages were able to be placed around the circumference of each pot, giving a total of 25 replicates. To minimise variation within the experiments due to weevil size, only large adults were selected from the field collection weevil sample. Although not sexed, this selection process meant that most were probably female.

The time the adults were put into the Petri dishes was recorded. If feeding commenced within a few minutes, the duration of this first feeding episode was monitored and noted. The number of notches made by each adult was recorded at hourly intervals for the first $5 \mathrm{~h}$, then at 8 and $24 \mathrm{~h}$. The $8 \mathrm{~h}$ dark phase occurred midway between the latter recordings. After $24 \mathrm{~h}$ a new leaf was introduced into each Petri dish, tagged with a tietag on the petiole that was slipped through the same slot as the petiole of the old leaf. The number of feeding notches on both leaves was recorded $48 \mathrm{~h}$ after the experiment commenced. The areas and dry weights of leaf material remaining were measured, and from the measurements of the notch areas, it was possible to calculate the amount of dry matter consumed.

\section{Outdoor experiment}

A similar experiment was repeated outside in February 2005 using 22-month old cv. Grasslands Kopu and cv. Grasslands Prestige clover plants grown with ryegrass in $1 \times 1 \mathrm{~m}$ plots. There were three plots of each cultivar and five replicates per plot. The weather was warm and sunny. In this experiment, each adult was caged on two leaves from the commencement of the experiment and the number of notches on each leaf was recorded at 2, 4 and $24 \mathrm{~h}$. The leaf areas and dry matter consumed were measured as above. The adults used were chosen at random and their weight and sex was determined at the completion of the experiment.

\section{Statistical analysis}

The controlled environment data collected at completion of the experiment, including the comparison between predicted and actual notching, were analysed by one way ANOVA as there was no variability between plants. The outdoor data collected at completion of the experiment were analysed by regression with log transformation of $\%$ leaf area data. For several variables there was a significant sex $\times$ cultivar interaction. For these variables the two sexes were analysed separately. Paired t-tests were used to compare notching on leaves between time intervals.

\section{Controlled environment experiment}

All adults commenced feeding within the first hour of the experiment. The mean length of time taken to make a single notch by the adults observed feeding was $8 \pm 1 \mathrm{~min}$ $(\mathrm{n}=10)$. After feeding the adults moved off the leaf and commenced grooming. Although resting position was not recorded, both authors observed that non-feeding adults were usually found in the lowest section of the cage. Overall, adults made $4.7 \pm 0.3$ feeding notches/day, equating to an average interval between feeding episodes of $5.0 \mathrm{~h}$. However, when the time interval between feeding episodes is calculated for the observations made at hours 3-8 inclusive when adults were exposed to continuous light, the mean time was significantly shorter at $2.9 \mathrm{~h} /$ notch $(\mathrm{SED}=0.2, \mathrm{P}<0.001)$.

No significant difference was found between the numbers of feeding notches on the fresh leaves introduced after $24 \mathrm{~h}(2.5 \pm 0.4)$ with the expected number $(2.3 \pm 0.2)$ if feeding was random between the old and new leaf. The notches made by adults on cv. Crau were noticeably large, averaging $8.1 \pm 0.4 \mathrm{~mm}^{2}(0.24 \pm 0.01 \mathrm{mg} /$ notch $)$. Overall, each adult consumed $38.6 \pm 3.2 \mathrm{~mm}^{2}$ of foliage per day, the equivalent of $1.2 \pm 0.1 \mathrm{mg}$ dry matter. 
Crau had large leaves $\left(9.67 \pm \mathrm{cm}^{2}\right)$ and the foliage was noticeably soft to handle. This is typical for Crau in the field and was reflected in a relatively low tissue density per unit area $\left(3.0 \mathrm{mg}\right.$ dry matter $\left.(\mathrm{DM}) / \mathrm{cm}^{2}\right)$.

\section{Outdoor experiment}

Four adults escaped during the experiment and feeding data relating to these weevils have been omitted from the analyses. There was no evidence that a leaf notched within the first $2 \mathrm{~h}$ of the experiment was any more or less susceptible to attack within the following $2 \mathrm{~h}(0.27 \pm 0.09$ versus $0.23 \pm 0.07$ notches/leaf on previously notched and unnotched leaves respectively).

Overall, adults feeding on Kopu or Prestige made $6.3 \pm 1.1$ feeding notches in $24 \mathrm{~h}$ and consumed $0.86 \pm 0.09 \mathrm{mg}$ per day. As anticipated, a higher percentage leaf area $(3.2 \%)$ of the small-leafed Prestige was eaten in comparison to the large-leafed Kopu $(1.5 \%, \mathrm{P}<0.01)$ (Table 1$)$. When all data were pooled, the amount consumed was linearly related to weevil size (Fig. 1), with females eating significantly more mg clover DM per day $(1.0 \mathrm{mg} /$ day $)$ than males $(0.7 \mathrm{mg} /$ day, $\mathrm{P}<0.05)$. While there was considerable variation in weevil size, the largest weevils were female, with six females exceeding $8 \mathrm{mg}$ (Fig. 1). The mean notch size on Kopu tended to be larger than those on Prestige $(\mathrm{P}<0.05$, Table 1$)$.

TABLE 1: Mean feeding measurements of adult clover root weevil confined on two attached Kopu and Prestige white clover leaves in the field for $24 \mathrm{~h}$.

\begin{tabular}{llcclc}
\hline & \multicolumn{1}{c}{ Sex } & Kopu & Prestige & SED & P-value \\
\hline Leaf area/leaf $\left(\mathrm{cm}^{2}\right)$ & & 7.57 & 3.48 & 0.47 & $<0.001$ \\
Leaf area/notch $\left(\mathrm{mm}^{2}\right)$ & & 4.7 & 3.7 & 0.4 & 0.016 \\
DM/notch $(\mathrm{mg})$ & & 0.15 & 0.12 & 0.02 & 0.143 \\
No. of notches & females & 4.2 & 9.5 & 1.3 & 0.003 \\
& males & 7.5 & 3.8 & 1.0 & 0.006 \\
Leaf area eaten $\left(\mathrm{mm}^{2}\right)$ & females & 24 & 37 & 6 & 0.059 \\
& males & 28 & 14 & 5 & 0.024 \\
\% Leaf area eaten & & & & & \\
& females & 1.5 & 4.9 & 1.0 & 0.005 \\
DM eaten $(\mathrm{mg})$ & males & 1.7 & 1.8 & 0.57 & 0.917 \\
& females & 0.75 & 1.21 & 0.19 & 0.038 \\
& males & 0.86 & 0.50 & 0.19 & 0.105 \\
\hline
\end{tabular}

${ }^{1}$ Back transformed data.

While the sample size was small (six males and six females on Kopu, and eight females and six males on Prestige), apparent sex differences in feeding behaviour were detected (Table 1). Females ate more Prestige than Kopu in terms of number of notches $(\mathrm{P}<0.01), \mathrm{DM}(\mathrm{P}<0.05)$ and \% leaf area $(\mathrm{P}<0.01)$, while males ate more Kopu than Prestige (notches $\mathrm{P}<0.01$; leaf area $\mathrm{P}<0.05$ ). This resulted in females consuming over twice as much Prestige DM than males, while males consumed $15 \%$ more Kopu than females (Table 1).

The plants used were typical of their respective cultivars with Prestige having smallmedium sized leaves and Kopu having large leaves (Table 1). The tissue density was $3.2 \pm 0.1 \mathrm{mg} \mathrm{DM} / \mathrm{cm}^{2}$ for Kopu and $3.4 \pm 0.1 \mathrm{mg} \mathrm{DM} / \mathrm{cm}^{2}$ for Prestige.

\section{DISCUSSION}

The observations made during these experiments indicate that CRW adults have short episodes of feeding interspersed with long periods during which they digest the consumed foliage away from the leaf surface. This behaviour may limit their exposure to parasitoids, bird predation or ingestion by grazing animals. Feeding took place in bright sunlight outdoors, and the difference in feeding rate in the first $8 \mathrm{~h}$ (continuous light) and that for the full $8 \mathrm{~h}$ dark: $16 \mathrm{~h}$ light photoperiod in the controlled environment experiment suggests that feeding ceases in the dark. 


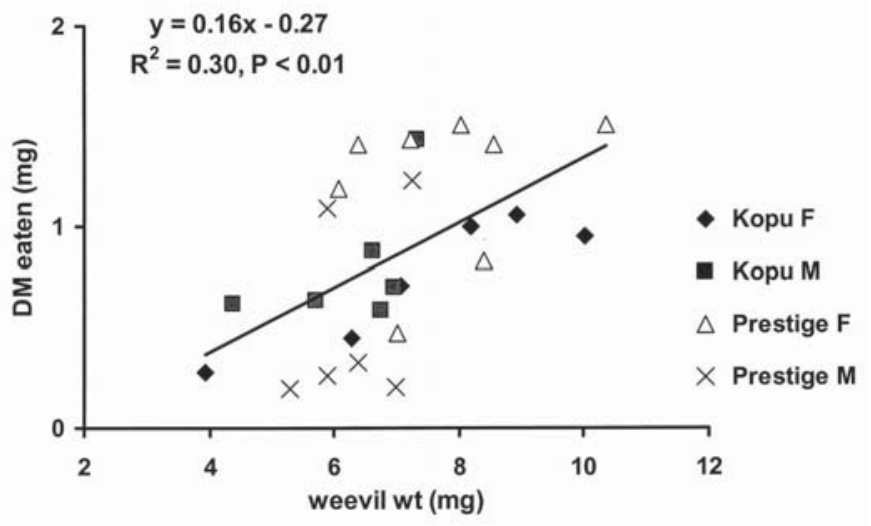

FIGURE 1: The relationship between dry matter consumed and weight of male (M) and female (F) clover root weevil adults confined on two attached Kopu and Prestige white clover leaves in the field for $24 \mathrm{~h}$.

While there was a significant relationship between weevil size and the amount of foliage ingested in the outdoor experiment, it appeared that the interaction between clover cultivar and weevil sex was also important in determining feeding rate. Reproductive females are likely to be voracious, as Evans et al. (1997) had found reproductive $S$. discoideus females consumed about four times more foliage than males and non-reproductive females. However, the reason why females appeared to eat more Prestige and the males Kopu are unclear. One possibility is that the two cultivars have subtle differences in nutritive value and that the sexes have different requirements. Sex-specific feeding modes have been observed in other weevils, for example Bruchidius dorsalis (Fahraeus) males visit non-host flowers to feed on the pollen and nectar while the females remain on the host plant (Takakura 2004). Another is that Prestige has denser tissue than Kopu, and if effort expended is a factor in feeding duration, leaf toughness may affect the smaller adults. DM ingestion rather than effort expended would seem a factor for females. Comparison of results shows that while notches made by females on Prestige were almost half the size of those on Crau, the DM consumed over $24 \mathrm{~h}$ was almost identical. However, as the experiments were not designed to investigate role of sex in leaf herbivory, the findings are based on a very small test population and mainly serve to highlight where further research is warranted.

Prestige and Crau have been reported to have greater insect resistance than some other commercial cultivars (Caradus \& Woodfield 1997) and possible mechanisms include defence compounds. These can be present in the plant at all times or only produced when attacked. For example, when infected by the stem nematode Ditylenchus dipsaci Kuhn, formononetin accumulates in the meristems of resistant white clovers, but not in susceptible plants (Cook et al. 1995). However, there was no evidence that adults preferred undamaged leaves over leaves that had been recently notched in the three white clover cultivars tested. Mowat \& Shakeel (1989) found that cyanogenic potential was a factor in level of weevil damage. Prestige has high $\mathrm{HCN}$ production with $69 \%$ plants cyanogenic compared to $\mathrm{Crau}$ (moderate $\mathrm{HCN}$ production with $100 \%$ plants cyanogenic) and Kopu (moderate HCN production with 51-55\% plants cyanogenic) (Caradus \& Woodfield 1997). The results from these experiments suggest HCN production does not inhibit female feeding. 
The levels of feeding in these experiments range from similar, to a third less than those reported on other cultivars by Wiech \& Clements (1992), Murray \& Clements (1993) and Hardwick (1998), all of whom used starved adults. So what does this mean in terms of loss of forage production? Using unpublished peak spring and autumn pupal numbers from 1998-2005 at a site monitored in the Waikato, and to simplify calculations, assuming all resulting adults lived one month in summer and three months in autumn, the amount of clover consumed equates to $53 \mathrm{~kg} / \mathrm{ha} /$ annum. As a single cow can consume that quantity of clover within 4 days, it is apparent, as previously assumed, that adult feeding on mature clovers is not a significant problem in most years.

\section{ACKNOWLEDGEMENTS}

The authors wish to thank Catherine Cameron for analysis of data. This project was supported by the Foundation for Research, Science and Technology.

\section{REFERENCES}

Caradus JR, Woodfield DR 1997. World checklist of white clover varieties II. New Zealand Journal of Agricultural Research 40: 115-206.

Clements RO, Murray PJ 1992. Studies on the feeding of Sitona lineatus L. (Coleoptera: Curculionidae) on white clover (Trifolium repens L.) seedlings. Annals of Applied Biology 121: 233 -238.

Cook R, Tiller SA, Mizen KA, Edwards R 1995. Isoflavenoid metabolism in resistant and susceptible cultivars of white clover infected with the stem nematode Ditylenchus dipsaci. Journal of Plant Physiology 146: 348-354.

Evans AA, Barratt BIP, Chapman RB 1997. Feeding by Sitona discoideus after exposure to the parasitoid Microctonus aethiopoides. Proceedings of the 50th New Zealand Plant Protection Conference. Pp. 47-50

Gerard PJ, Hackell DL, Willoughby BE 2004. Insights into clover root weevil larval feeding. Proceedings of the 8th Australian Conference on Grassland Invertebrate Ecology. Pp. 49-57.

Hardwick S 1998. Laboratory investigations into feeding preferences of adult Sitona lepidus Gyllenhal. Proceedings of the 51st New Zealand Plant Protection Conference. Pp. 5-8.

Mowat DJ, Shakell MA 1989. The effect of different cultivars of clover on numbers of, and leaf damage by, some invertebrate species. Grass and Forage Science 44: 11-18.

Murray PJ, Clements RO 1993. Feeding preferences among eleven cultivars of white clover (Trifolium repens) by adults of two species of Sitona weevil (Coleoptera: Curculionidae). Tests of Agrochemicals and cultivars 14 (Annals of Applied Biology 122, Supplement): 134-135.

Murray PJ, Clements RO 1994. Investigations of the host feeding preferences of Sitona weevils found commonly on white clover (Trifolium repens) in the UK. Entomologia Experimentalis et Applicata 71:73-79.

Murray PJ 1996a. Influence of food source on feeding, longevity and fecundity of Sitona flavescens (Coleoptera: Curculionidae), a major pest of white clover in the UK. In: Frame J ed. Recent research and development on white clover in Europe. FAO/CHIHEAM, Estonia. REU Technical Series 42: 18-121.

Murray P J 1996b. Evaluation of a range of varieties of white clover for resistance to feeding by weevils of the genus Sitona. Plant Varieties and Seeds 9(1): 9-14.

Takakura K 2004. The nutritional contribution of males affects the feeding behavior and spatial distribution of females in a bruchid beetle, Bruchidius dorsalis. Journal of Ethology 22(1): 37-42.

Wiech K, Clements RO 1992. Studies on the Sitona spp. and Apion spp. weevils feeding on white clover foliage at a site in S.E. England. Journal of Applied Entomology 113(5): 437-440. 